\title{
Feeding island dreams: exploring the relationship between food security and agritourism in the Caribbean
}

\author{
Adelle Thomas \\ adelle.thomas@ub.edu.bs \\ Visiting Researcher, University of The Bahamas \\ Senior Caribbean Research Associate, Climate Analytics
}

Amelia Moore
ameliamoore@uri.edu
Assistant Professor, University of Rhode Island
Michael Edwards
michael.edwards@ub.edu.bs
Assistant Professor, University of The Bahamas

ABSTRACT: Caribbean islands have increasingly turned to tourism as a pathway for economic advancement, often to the detriment of other industries, particularly agriculture. The influx of millions of tourists to these island destinations increases food demand, escalates food importation, and oftentimes results in food insecurity. Agritourism, an alternative tourism form, has been proposed as a way to stimulate domestic food production and increase food security. This article provides a selective examination of the possibilities of relationships between agritourism and food security in the context of a specific Caribbean island: New Providence, Bahamas. Drawing from semi-structured interviews and site visits with over sixty farmers, we focus on the experiences of three farms that have attempted to engage in agritourism, with different approaches, levels of success, and potential impacts on food security. We find that the potential for agritourism to transform food security for Caribbean islands is constrained by demand and the consumption standards of both residents and tourists. The type of agritourism that has thus far proven to be most appealing to tourists is unachievable for the majority of farmers, has inconsequential contributions to island food security, and privileges wealthy farmers. Unfortunately, in its current form, agritourism is not yet a viable solution for the food security issues of New Providence, let alone other Caribbean islands.

Keywords: agriculture, agritourism, Bahamas, Caribbean, food security, islands, sustainable tourism https://doi.org/10.24043/isj.66

(C) 2018 - Institute of Island Studies, University of Prince Edward Island, Canada.

\section{Island dreams}

Small islands across the Caribbean have undergone significant economic shifts following the wave of independence post-World War II. While industries such as agriculture and manufacturing were dominant in the region during the era of colonization, the expansion of tourism was touted as a way to modernize economies, stimulate foreign exchange, and decrease inequality and poverty (Mullings, 2004). Many of these newly sovereign countries 
thus turned to tourism as a pathway for economic advancement, gambling on the dream that their sandy beaches, turquoise seas, and inviting climates would lure Euro-American tourists and ensure financial stability (Pattullo, 2005). Tourism rapidly grew as a major industry within the region, becoming one of the main contributors to revenue generation and job creation (Thacker \& Perrelli, 2012). However, the growth of tourism came at the expense of other sectors, in particular agriculture (Modeste, 1995). The focus on tourism and other tertiary sectors, along with the loss of preferential access to markets, destruction of crops due to extreme events and diseases, and structural adjustment policies led by international agencies such as the World Bank, contributed to the constriction of agricultural sectors across the region (Friedmann \& McMichael, 1989; Timms, 2006). Countries such as Jamaica, which once had a thriving agricultural industry, saw a steady decline of the sector resulting in the need to import significant amounts of food (Rhiney, 2011). Indeed, the decline of agriculture within the region has resulted in domestic food production being dwarfed by the influx of imported foods. Almost all Caribbean countries import more than $60 \%$ of the food that they consume, with half of them importing more than $80 \%$ of total food consumption (FAO, 2015).

Declining agricultural industries, along with the need for greater amounts of food to meet the requirements of residents and the millions of tourists who oftentimes exceed national populations, have led to a state of food insecurity for many countries within the region (CARICOM 2011). Food insecurity has been defined as "the limited or uncertain availability of nutritionally adequate and safe foods or limited or uncertain ability to acquire acceptable foods in socially acceptable ways" (Anderson, 1990, p. 1559). Dependence on food importation exposes countries to volatile food prices while high levels of income inequality and unemployment often lead to inability of those beneath the poverty line to afford high-quality and nutritious food, resulting in the prevalence of diabetes and obesity (ECLAC, 2008; FAO, 2014). Further, the vulnerability of the region to natural hazards can inhibit the ability of countries to import food, from both logistical and financial standpoints, while global economic shocks reduce levels of remittances and result in quality food being priced beyond the reach of the poor (FAO, 2015).

As food insecurity has been increasingly identified as a significant challenge for the region, the question of whether tourism can be utilized as a tool to increase food security, rather than contributing to insecurity, has been raised (CARICOM, 2011). An alternative form of tourism, agritourism, has been proposed as a way to capitalize on existing tourism industries within the Caribbean to stimulate domestic food production and lead to greater levels of food security (Collins, 2000; Harvey, 2011; Hepburn, 2013). Agritourism, also referred to as agro-tourism, farm tourism or farm-based tourism, has a host of definitions but can be understood as a form of tourism in which there is some interaction between tourists and agricultural activities (Philip et al., 2010). Although there have long been calls for increasing linkages between agriculture and tourism within the region, these sectors have largely been viewed as discrete industries and there has been little study on agritourism in particular as a viable means of increasing food security (e.g., Timms, 2006; Wiley, 1998).

This article provides a selective examination of the possibilities of relationships between agritourism and food security in the context of a specific Caribbean island: New Providence, located in The Bahamas. Similar to other countries within the region, The Bahamas has long struggled to ground its tourism industry and its domestic economy within the archipelago and within Bahamian sovereign control (Cleare, 2007). Yet dependence on foreign capital, foreign goods, foreign expertise, and foreign markets remains the norm in the postcolonial present. National self-sufficiency is a perpetual goal, perpetually deferred. Within this Bahamian context, we explore existing and potential agritourism in New Providence and connections with food security. Drawing from semi-structured interviews and site visits with 
over 60 farms conducted in early 2016, we also explore how agritourism may result in uneven privileging of particular types of farms. We focus on the experiences of three farms that have attempted to engage in agritourism, with different approaches, levels of success, and potential impacts on food security. These ethnographic studies are supplemented with the views of local agricultural and tourism actors to obtain deeper insight on the potential for linking agritourism and food security in the island nation.

\section{Agritourism and food security: a global review}

As tourism has increasingly been used as a means for economic advancement in developing countries, the argument has been made that there is immense potential to maximize benefits by linking the sector with other industries, particularly agriculture (Ashley et al., 2006; Belisle, 1983; Rogerson, 2012). Forging greater relationships between tourism and agriculture in the Caribbean is also viewed as imperative to reduce high levels of economic leakages, diversify economies, conserve cultural heritage, increase food security, and reduce poverty (IICA, 2013). The concept of agritourism encompasses the broad variety of linkages that can be found between agriculture and tourism and can take many forms. Drawing on experiences from within the Caribbean, Harvey (2011) defines six categories of agritourism, including the provision of food for tourist consumption by farmers, tourist visitation to working farms or prior agricultural sites, and the inclusion of tourists in food festivals, fairs, or markets. Other typologies categorize agritourism depending on whether the interaction between visitors and agriculture is passive or direct, whether activity takes place on a working farm or not, and whether the tourist has an authentic or staged agricultural experience (Flanigan et al., 2014; Philip et al., 2010). In our reading, agritourism can be viewed as consisting of two broad categories: (i) indirect agritourism, which focuses on the supply of food by local agriculturists for tourist consumption, and (ii) direct agritourism, which emphasizes active interaction between tourists and the agricultural industry in agricultural space. These two categories have also been described as (i) backward linkages, centring on connections among agricultural entities, hotels, and restaurants, and (ii) forward linkages, which focus on direct interaction between agricultural entities and tourists (Cai et al., 2006). In this article, while we explore both forms of agritourism, we focus on direct agritourism as these forward linkages are a burgeoning industry in the region and have also been understudied, particularly in island settings (Karampela et al., 2016).

Indirect forms of agritourism focus on the provision of produce, livestock, value-added goods (such as sauces and jams), and other agricultural products to restaurants, stores, hotels, and other enterprises that are patronized by tourists. These backward linkages between tourism and local agriculture are intended to promote lower carbon economies through reduced shipping of produce to destinations, help prevent economic leakages by keeping profits within the country, and increase tourism-related employment beyond hotels and onto the farms that support tourism enterprises (Pillay \& Rogerson, 2013). This more passive form of agritourism envisions tourism as an impetus to increase food security through the rejuvenation of local agricultural sectors (Telfer \& Wall, 2000). There are also potential linkages between agriculture and pro-poor tourism whereby poor farmers may utilize existing skills to provide food for tourism establishments, providing an authentic food experience for tourists and spreading the economic benefits of tourism locally (Rogerson, 2012; Torres \& Momsen, 2004). However, there are a number of challenges associated with indirect agritourism, including the need to manage tourist expectations, limited communication and trust between agriculture and tourism sectors (which are often composed of socially distinct groups), and lack of governmental policy support (Pillay \& Rogerson, 2013). 
The majority of literature on tourism and agriculture in the Caribbean is focused on exploring these types of backward linkages, and many studies don't explicitly refer to these activities as agritourism. A number of studies critique the variety of linkages between hotels and farmers, finding that not all relationships prove to be beneficial for farmers due to high tourism industry standards, limited farmer access to capital and technology, and unreliability of supply to meet tourism demands (Belisle, 1983; Timms, 2006; Rhiney, 2011; Torres \& Momson, 2004). While indirect agritourism has the potential to result in thriving domestic agriculture sectors, there must be deliberate efforts to prevent a solitary focus on providing food for tourist consumption while ignoring the needs of local residents, thereby failing to improve food security. There is also acknowledgement that domestic agricultural sectors must be revamped in order to meet the demands of both tourists and local residents (Timms, 2006; Torres \& Momson, 2004). Building the capacity of local farmers to boost production, developing farmers' associations, and making connections with tourism representatives are also identified as key needs (Rhiney, 2011).

Direct agritourism focuses on creating spaces where tourists and agriculturists can interact. These forward linkages may take the form of sharing agricultural heritage through visiting historical agricultural sites, having tourists participate in farm tours, including tourists in farmers' markets or food festivals, and having tourist accommodations built directly on farms (Flanigan et al., 2014). Direct agritourism is promoted as having a plethora of benefits at the farm level, including increasing revenue, providing avenues for further employment opportunities on farms, and mitigating against risk during times of poor harvest or reduced market values (Tew \& Barbieri, 2012). While there have been a number of studies on the benefits of agritourism for farms and communities, there has been limited engagement in how direct agritourism might promote food security (Amsden \& McEntee, 2011).

Studies centred on the Caribbean that address the potential for direct agritourism mostly focus on investigating opportunities and challenges facing existing agritourism establishments. These studies have found that while there is potential for greater expansion of agritourism in the region, challenges such as lack of financing, limited fiscal incentives, and the absence of clear and effective policies and programs to encourage agritourism development have inhibited growth of these types of establishments (Collins, 2000; Harvey, 2011; IICA, 2013; Rhiney et al., 2015). There are also challenges with balancing agritourism development with environmental preservation and finding innovative ways of attracting different types of tourists to an agritourism experience (Collins, 2000; Rhiney et al., 2015). For islands that rely on mass tourism, visitors may be more interested in the sun, sand, and sea experience and less open to engaging and interacting in cultural activities, such as forms of direct agritourism. While some studies do include limited discussion on the potential for agritourism to affect food security, mostly through stimulation of agriculture, the focus is largely on the benefits of agritourism in diversifying tourism products, creating employment, and contributing to greater economic resilience on national scales. Notably, Hepburn (2013) has explicitly explored the connection between direct agritourism and food security in the Bahamas through linking the interest of tourists in participating in agritourism activities to potential implications for food security. Through a survey of tourists, the study finds that many are interested in farmers' markets and product tasting: interests that can be met through the development of agritourism enterprises that could, in theory, increase local agricultural production and improve island food security.

While there is limited literature on direct agritourism within the Caribbean, other regions provide case studies of ways that these forward linkages have been implemented, with some 
examples from other island settings. In the US, agritourism has taken a variety of forms and is linked with increasing the potential for more profitable on-farm sales of value-added products and services, a benefit particularly attractive to smaller farms that may be facing financial hardship (McGehee, 2007). Scholars have noted that there are common characteristics of American farmers who participate in agritourism, including farmers who are younger, are college educated, have access to the Internet, or pay for advice. Farms that have a large percentage of land unsuitable for crops, are located near central cities, or are organized as corporations are also more likely to engage in agritourism (Bagi \& Reeder, 2012). Direct agritourism appears to be touted as a means to stabilize farms that are suffering from economic strains due to declining prices, decreased sales, or expanding production costs, but this may only work for farms near urban centres that can generate demand for farm excursions. In the archipelago of Hawai'i, island tourism has been found to positively influence some sectors of the agricultural export industry. As American tourists returned home with new appreciation for Hawai'ian-grown produce, a market on the mainland cultivated the development of exportation of Hawai'iangrown products (Cox et al., 1994). Hawai'i would seem to be an important case for the Caribbean, but it seems that for much of the $20^{\text {th }}$ century tourism primarily enabled the creation of an export market for products branded as "typically Hawai'ian." There has been no sustained discussion of the relationship between tourism and food security or between tourism and forms of small-scale agriculture that benefits local populations or is even sold to them.

In Europe, agritourism takes the form of an alternative strategy to standard farm production. In tourist centres farmers find engaging directly with tourists to be far more lucrative than indirect linkages. In England, agritourism is assumed to be a panacea for rural areas with few development options (Busby \& Rendle, 2000). Farmers most interested in agritourism are those who are most in debt and in need of cash and those whose children wish to remain in the business in a declining agricultural sector. While agritourism does not seem to increase profits, it can stabilize local farms so they can stay open through all seasons and at small scales. Many farmers consider agritourism to be a separate business from farming and do not wish to give up their farming identity, even as they engage in agritourism (Sharpley \& Vass, 2006). In Italy, larger farmers are seen to be more capable of making the shift to agritourism because they have more capital and can absorb the risk of investing in tourist infrastructure. Age also is a structural factor and older farmers are less likely to venture into agritourism because their goals are more short-term (Sonnino, 2004).

In the Gulf Cooperation Council (GCC) region of the Middle East, Pirani and Arafat (2016) explain that growth in tourism means growth in food demand, consumption, and also food waste. The region is a large food-waste generator, with $30 \%$ of all purchased food in hotels and malls being wasted, and so food demand must be managed in terms of behaviour change to minimize food waste. In Israel it was found that tourists in rural areas did not care much about the farm factor as a major component of rural tourism but that farms in tourism cluster areas produce more product and have higher-valued accommodations (Fleischer \& Tchetchik, 2002). In the Middle East there is acknowledgement of the need for food security concerns to be addressed in discussions of the food demand linkages between tourism and agriculture, but direct forms of agritourism do not appear to be widely prevalent. Israel may be an exception to that assessment, but even in that case rural farms seem to be the beneficiary of tourist dollars that stabilize their income in tourist regions, and if these agritourist farms do produce more product, it is not clear where that product goes or who it feeds.

In Southeast Asia forward linkages may be deemed unnecessary in many places if local agriculture can be supported by the tourism industry through backward linkages. In the island 
of Lombok, Indonesia, Telfer and Wall (1996) explore the challenges facing agritourism, including lack of communication and understanding between sectors, tourists' preferences for the familiar, and competition for land, labour, water, and domestic capital. In very poor subsistence areas that are nonetheless growing rural tourism locales, such as in parts of rural Thailand, local household gardens with vegetables and other produce are encouraged for local food production and tourist consumption. The goal is cheap, locally produced, healthy food that supports community resilience but that also has a unique local identity to attract tourists (Sikiram, 2014). Some direct small-scale, community-based agritourism, such as home stays or guest houses, can improve highly localized forms of food security by encouraging households to grow local nutritious foods to serve tourists and ultimately themselves. In the island of Taiwan, resource use, pollution, and landscape change are impacts of tourism, but promoting agro-ecotourism can supposedly have benefits like organic production and improved environmental quality (Kuo \& Chiu, 2006). These authors see agro-ecotourism, which addresses environmental concerns, as superior to conventional agritourism and claim it should be the optimal rural policy for Taiwan.

In the Indian Ocean, residents of Mauritius view agritourism as a positive factor in improving community well-being (Naidoo \& Sharpley, 2016). Agritourism is perceived as offering greater potential to enhance the security and welfare of community members as compared to resort-based enclave tourism. Similarly, island communities in China view agritourism as increasing revenue and reinforcing island identity ( $\mathrm{Su}$ et al., 2017). In this context, agritourism takes the form of sharing fishing culture and practices rather than landbased agriculture-capitalizing on the fisheries-based livelihoods of these island communities.

While our global review is not limited to islands alone, it is by no means exhaustive. However, these representative examples of the existing literature show that a great deal of direct agritourism around the world does not yet explicitly address food security, and in many cases the relationship between agritourism and food security must be inferred. Direct forms of agritourism, where they exist, are frequently utilized as a rural development strategy to provide income. In many cases agritourism is not necessarily tied to local, national, or regional food security via food production at all, except at the very small scale in developing economies where agriculturists might not be producing much at all for themselves if it weren't for the presence of tourists, thereby improving their own diets as they cater to guests.

\section{Agriculture and tourism in New Providence}

The Bahamas is a small island archipelago in the western Atlantic Ocean on the northern edge of the Caribbean region. Consisting of over 700 islands, astronauts have remarked that this island nation is one of the most beautiful places on Earth when seen from space; these islands are the stuff of dreams. The tourism industry of The Bahamas has expended significant time and energy selling the islands of The Bahamas as some of the most beautiful places on Earth when visited as a Euro-American vacation destination (Cleare, 2007; Moore, 2015). New Providence island is the seat of the Bahamian capital, Nassau, the home to the majority of the nation's citizens, and the site of the majority of the nation's tourist arrivals.

The USA, less than 200 miles from New Providence, provides over $80 \%$ of tourists to the island (Thomas, 2012). The tourism product in New Providence is targeted towards relatively affluent mass tourists who are attracted to large resorts that offer the sun, sand, and sea experience along with casinos (Cleare, 2007; Pattullo, 2005). Large resorts, concentrated on the northern shores of the island near Nassau, offer immersive experiences where tourists do not need to leave the premises. A variety of restaurants, entertainment options, and 
shopping experiences are offered at these resorts, diminishing the need for tourists to venture to other parts of the island. While there are a number of smaller, locally owned or operated hotels, these establishments cater to the minority of international guests and are often used for business travel or for accommodation by tourists who are visiting friends and family (Thomas, 2012). In addition to stopover tourists, the majority of visitors to New Providence arrive via cruise ship. As one of the major Caribbean cruise destinations, New Providence welcomes 2.6 million cruise-ship tourists per year, dwarfing the resident population of approximately 250,000 (Department of Statistics, 2015; Ministry of Tourism, 2017). These visitors tend to remain close to downtown Nassau, where the cruise-ship port is located.

Despite its overabundance of tourism, New Providence has one of the largest agricultural landholdings in the nation and has also been an integral part of a number of historic plans for the expansion of the nation's agricultural sector. Perhaps the most significant development was the Millar's Road Agricultural Development Project in the 1970s where 500 acres of Crown Land, land in the property of the state, was made available for both established and aspiring farmers (Eneas, 1998). A large area in southwest New Providence, centred around Cowpen Road, was set aside for farm leases for small-scale local farming and was designated as an agricultural centre, adjacent to the urban density of Nassau. It was envisioned that this agricultural corner could feed the island, provide wholesome local produce to the majority of residents regardless of income level, and stabilize the local agricultural economy. Islanders took up these leases and the area became known as a place for farming on an island that otherwise looked to the expanding Caribbean tourism industry as the national standard for modern development and consumptive lifestyles.

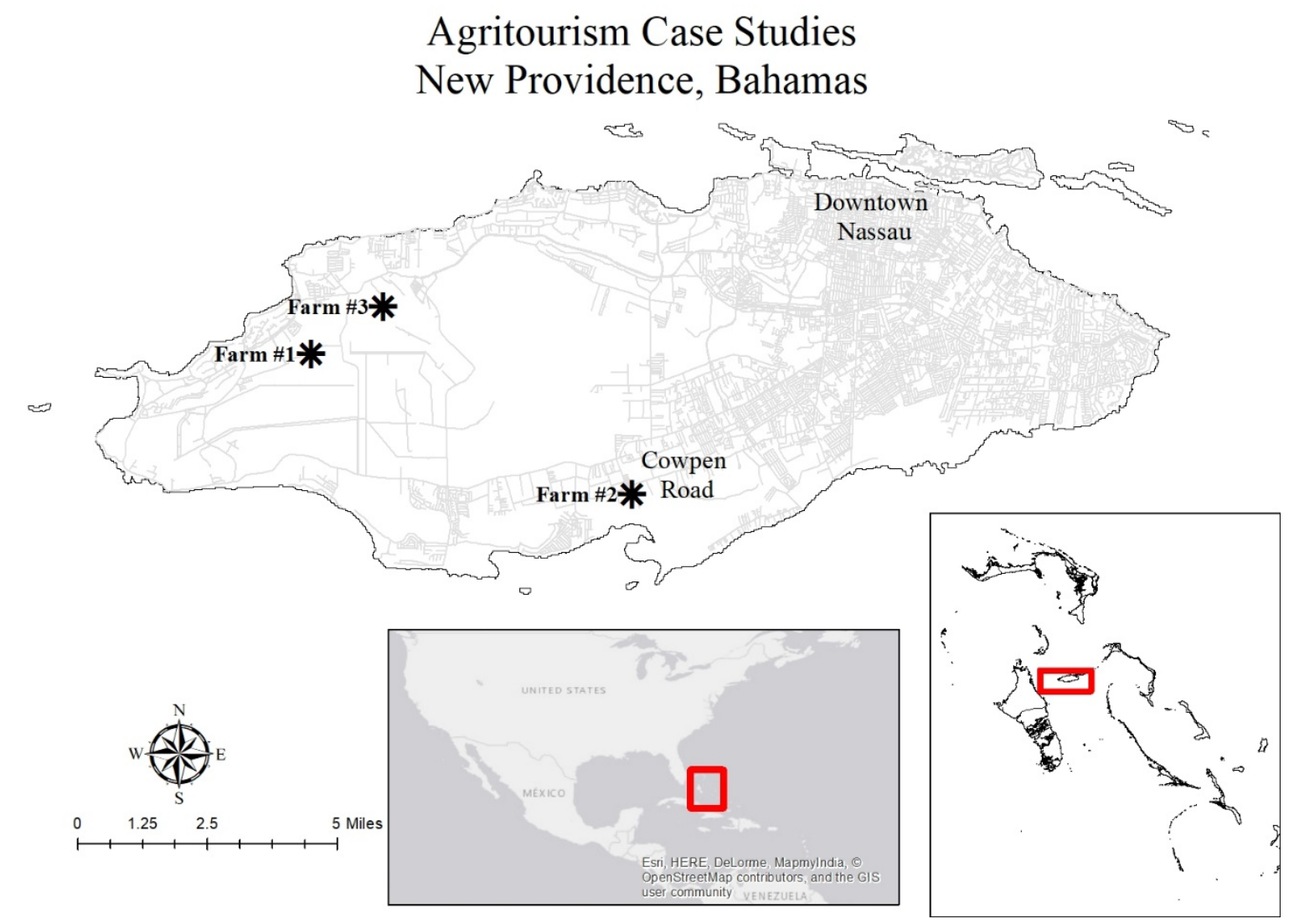

Figure 1: Agritourism case studies. 


\section{Methodology}

In order to investigate the current state of agriculture and agritourism in New Providence, the authors, along with a team of students and colleagues, administered semi-structured interviews and site visits with approximately 60 current and former farmers on the island between February and March of 2016. In the absence of a formal farmer registry, a list of farmers was compiled using input from the Bahamian Ministry of Agriculture, Inter-American Institute for Cooperation on Agriculture (IICA), and local researchers. The vast majority of contacted farmers agreed to participate in the study that focused on farmers' perspectives on local food production. Interviewees were asked about their background and training in agricultural practices, crop yields, sales, profitability, and details on how and to whom they sold their products. Information about the size and ownership of the farms along with existing or potential relationships with tourism stakeholders and other farmers was also obtained. Site visits were made to active farms (producing crops) and lasted between one and three hours. Detailed ethnographic observations were made on the type of farming methods utilized, crops and livestock present, and existence and state of farm infrastructure. Interviews were transcribed and qualitative content analysis was utilized to determine themes related to existing agricultural activity, potential and challenges for agritourism development, and the linkages between agritourism and food security.

To round out our study of agriculture and the potential for agritourism in New Providence, we also conducted semi-structured interviews with governmental representatives, buyers from local grocery store chains, and one prominent island chef who is known for sourcing produce locally.

\section{Results}

Our results are divided into two categories: interviews and case studies. The interviews yielded an important snapshot of the current state of agriculture on New Providence as well as narratives explaining how the present shape of agriculture came to be from the perspective of both current and former farmers and members of the farming industry. In addition to interviews, site visits and observations on farms helped us identify those farms that most closely fit the bill of direct agritourist destinations. At present only three farms identified themselves and were readily identified by others as engaging in agritourism on an island that receives millions of annual tourist arrivals.

\section{New Providence agriculture interviews}

Summarizing from our extensive interview data with farmers, we found that in the decades since the land was designated for farming, several different kinds of farms have struggled to emerge. Most farms consist of small- to medium-sized plots ranging between two and five acres. Farms are generally classified as either crop, livestock, or ornamental production, with most being used for a combination of crop and livestock. Similarly, farmers are not known to focus on any one crop but produce a wide array of crops depending on the season-the peak being the winter and spring months when temperatures are cooler. Farming methods vary from 'traditional' pot hole farms where seeds are placed in naturally formed holes in the limestone rock, to 'high tech' aquaponic closed systems that utilize live fish to fertilize a smaller array of hydroponically grown crops. However, the majority of farmers grow a few staple crops in irrigated beds utilizing well water. A few farms are intentionally organic, while some farms are considered organic by default because small-scale farmers cannot pay for expensive chemicals or fertilizers. Others utilize fertilizers and products subsidized by the government or imported from abroad. 
Very little has changed since the 1970s in terms of land acquisition for farm development. Most farmers do not purchase Crown Land outright from the government but, instead, are given long-term lease contracts and initial land-clearing support for periods of 2025 years, once they demonstrate continuous production on their plots. Leases are discontinued due to arrested agricultural production or if farmers pass away. Over the years it has become customary for small farmers to construct housing structures either on or in close proximity to their plots for themselves or for seasonal hired laborers, precipitating an interesting mix of farmland and housing subdivisions in southwest New Providence.

Farmers are generally older and male, although there are a few farms run by younger families under the age of 50. Many farms are still run by the original lease holders or their family members, although we soon learned that the longevity of farms did not necessarily mean these family farms were 'successful'. Many famers on New Providence, especially in this agricultural area, no longer make a real living with farming, if they ever did. A great deal of the produce we saw is given to friends and family. For many, holding on to their minimally productive farms is important as a means to maintain lease of the land. Employees are typically of Haitian origin because they are said to work for less than Bahamian farm employees. The low percentage of Bahamian workers is also related to increases in employment in other industries, namely tourism and financial services, which attract a large percentage of the New Providence population. Most older farmers have adult children who have not followed them into the farming tradition; instead, they are pursuing other forms of employment.

The 1970s vision of having substantial commercial operations on this corner of the island never came to fruition. Instead, what has resulted are modest subsistence landholdings of various sizes scattered across the southwestern region of the island. This is indeed a far cry from the great agricultural vision of New Providence as being the nucleus of an agricultural system of far-flung food producers. Today, this area of New Providence is experienced as an anachronistic return to a former era of domestic food production, with scattered farms 'hiding out' from the urban sprawl that attacks the land from all sides. Most tourists never see this part of New Providence, and many residents may never venture there in their daily routines.

Why did these farm dreams 'fail' to lead to food security for New Providence? The main reasons explained by the farmers themselves seem to be that the cost of farm labour is high, Bahamian farm labour is scarce, and farm inputs like fertilizer are costly. Local produce is often rejected by local buyers, especially buyers from the tourism industry, because it does not meet standards for price, appearance, and consistency demanded by the international market. Bahamian residents, increasingly connected to other markets in a globalized world, have decreased consumption of native produce and have become accustomed to imported food items which local farms find difficult, or impossible, to compete with.

Our interviews with industry officials and buyers revealed mixed perceptions on possibilities and barriers to agritourism and potential linkages to food security in New Providence. Existing agritourism was perceived as mostly focusing on backward linkages between agriculturists and tourism-related establishments. The most financially successful of these were identified as a few large farms on the more rural islands of the Bahamian archipelago which sell directly to restaurants and hotels. Also identified were a few smallerscale agriculturists who provide produce, meat, seafood, and eggs to small restaurants and caterers. The high quality of food was recognized as a major benefit of local produce as interviewees intimated that items such as locally produced eggs and tomatoes often surpass the quality of imported items, which may look good but can be flavourless or unripe.

In terms of the island's potential for agritourism, industry interviewees recommended the development of farms and farm produce niche markets, which would allow agriculturists to fulfill desires that 'consumers don't yet know they want'. This would allow farmers to attract both domestic and international tourists. Capitalizing on linkages between diet and 
health would allow agriculturists to gain a wider market for fresh, local food. The development of value-added products such as jams, preserves, and pickles was seen as a way for agriculturists to utilize surplus produce and to garner higher profits. Farmers' markets where consumers can directly purchase goods were also identified as an area in need of development. While interviewees identified some strides in localized, market-based agritourism, such as a few small existing farmers' markets and an all-women producers' cooperative that has encouraged the participation of women in agriculture and in the production of spices and crafts, they all felt that there was much more room for growth.

Industry interviewees also identified a number of barriers that have inhibited agritourism development. One of the most common barriers identified was lack of access to land and financing. Given that direct forms of agritourism require development of infrastructure, such as restrooms and other facilities, financial investment is a necessity. In the opinion of a representative from the Ministry of Agriculture, the current system of leasing land is not conducive to the development of infrastructure for agritourism purposes because there is little incentive for the farmer to invest in infrastructure. Another challenge that was identified was the lack of consistency in the production of local food. When produce such as tomatoes, onions, and cucumbers are out of season in the Bahamas, the demand for them does not decrease, thus creating the need for imported items. Imported items were also identified as having more uniform quality, grade, and packaging sizes than their Bahamian counterparts. These factors, in addition to the lack of a reliable and rapid transport system from out islands to New Providence, has increased reliance on imported food by hotels and restaurants. The chef whom we interviewed described the challenges of relying on only local produce, stating that relying solely on locally produced food would necessitate changing the restaurant menu daily, depending on the availability of items. While a small restaurant or caterer may be able to accommodate an ever-changing menu, this model would not be ideal for larger establishments.

These barriers to agritourism were also linked to challenges in improving food security for the nation. The lack of a national plan on stimulating food production along with the prolonged focus on tourism to the detriment of other industries led a number of interviewees to doubt the potential of agritourism to increase food security. The absence of a new generation of farmers was also seen as a hindrance to achieving food security. Younger people were characterized as more interested in pursuing less labour-intensive careers, leading to a lack of farmers and the decline of the agricultural industry. As one agriculture industry official stated, "I feel sad for those who have given their life to it [agriculture]. Feeding sheep and putting potatoes in the ground, and when they close their eyes the bush will grow up over it and no one will remember them." However, other interviewees had more optimistic views. A representative from Bahamas Agriculture and Marine Science Institute (BAMSI) was confident that at least 30 crops could be produced within the nation, if people can be found to produce them, eliminating the need for importation and increasing food security. Other stakeholders also agreed that increasing food production is indeed possible and that changing island diets to rely on local, seasonal foods would go a long way towards greater self-sufficiency. 
Table 1: Benefits and barriers to agritourism in New Providence.

\begin{tabular}{|l|l|}
\hline Benefits & Barriers \\
\hline $\begin{array}{l}\text { The development of niche value-added } \\
\text { agritourism products and experiences can } \\
\text { attract more domestic and international } \\
\text { tourists and diversify the existing tourism } \\
\text { product; }\end{array}$ & $\begin{array}{l}\text { There is generally a decline in available land, } \\
\text { funding and interest by younger people for } \\
\text { farming operations; }\end{array}$ \\
$\begin{array}{l}\text { Farmers can adopt a smart zero food waste } \\
\text { approach to their operations that will allow } \\
\text { for increased profit margins through the } \\
\text { creation of a variety of value-added items } \\
\text { and experiences; }\end{array}$ & $\begin{array}{l}\text { which small farmers find difficult to provide } \\
\text { given limited funding sources; } \\
\text { not conducive to enabling farmers to } \\
\text { making sizeable investments in their } \\
\text { properties to facilitate agritourism; }\end{array}$ \\
$\begin{array}{l}\text { The market for local food production has due to the increasing appetite by } \\
\text { both tourists and residents to consume more } \\
\text { local, seasonal foods. }\end{array}$ & $\begin{array}{l}\text { There is often a lack of consistency in the } \\
\text { volume and quality of locally grown food } \\
\text { which increases the need for imported food }\end{array}$ \\
$\begin{array}{l}\text { There are direct correlations between high } \\
\text { quality local food and greater diet and health } \\
\text { performance. }\end{array}$ & $\begin{array}{l}\text { There is no comprehensive agriculture/food } \\
\text { policy to create an environment conducive } \\
\text { to significantly grow the local industry; }\end{array}$ \\
& $\begin{array}{l}\text { Governmental focus has centered on } \\
\text { traditional mass tourism development which } \\
\text { lowers possibilities for agritourism and food } \\
\text { security. }\end{array}$ \\
\hline
\end{tabular}

New Providence agritourism case studies

Farm \#1 is atypical for New Providence. It is 12 years old and all 50 acres of land are fully owned by a wealthy Bahamian who made his fortune in finance and whose family has a long history of farming and agricultural landholdings. His farm, located near an affluent residential enclave in the west of the island, is not associated with the leased farmsteads of Cowpen Road. The farm is organic and engages in both direct and indirect forms of agritourism. Microgreens along with other produce are supplied to the high-end restaurant sector and boutique hotels and a number of farm-based activities are offered that are frequented by both tourists and affluent residents. Visitors can tour the farm grounds and have lunch served al fresco on the grounds from the farm restaurant. The food is decidedly up-market and 'farm fresh' with salads, soups, and grains featuring heavily on the menu. The food tastes more like Napa California, and is indeed priced in that strata, than the usual Bahamian cuisine which is often more fried, breaded, and stewed. The self-guided farm tour features greenhouses with large scale aquaponics systems for the growth of 'niche crops' including cherry tomatoes, strawberries, and varietals of mint and basil, a system that the owner feels is the most sustainable way to farm. The owner opined that the Bahamian government has ruined farming by eradicating protective policies, leaving the country dependent on imports and drowning in crime as a result of poverty and government corruption. The owner stated that if crime levels did not decrease he would close his farm and move his restaurant to the nearby gated residential enclave, where only wealthy residents would have access to his products. Indeed, following our interview, the owner did move the restaurant to the enclave and the farm is no longer open to the public. 
Farm \#1 appears to be the most successful in direct agritourism and is often heralded as an example for other farms. Low acreage is required to produce its high-end crops and everything it produces is sold, donated, or turned into value-added products. The farm does indeed attract many visitors who will pay a premium to enjoy this style of upscale agritourism, with over 45,000 lunches being sold annually. But this farm is not exactly a model for island food security. The restaurant itself relies on goods sourced from Florida, which are flown in on the farmer's private plane. Microgreens, mint, and basil will not meet the food demands of the island. Only a wealthy person with direct access to capital could start a farm like this in New Providence, only affluent people can consume the farm's products, and few Bahamians benefit from the farm's existence. Instead of being a model for the development of island food security, Farm \#1 features a form of agritourism that is actually a brand of 'sustainable tourism' (Moore, 2015). The organic fields of greens, the aquaponics system, and the farm-to-table feel of the restaurant align with the prevailing aesthetics of 'green local business' that is a popular high-end product for an international, cosmopolitan clientele. This farm is most certainly a model for a viable business, but the actual sustainability of that business beyond catering to the elite is highly questionable. If anything, Farm \#1 helps to stabilize a luxury tourist market in The Bahamas, rather than stabilizing any real capacity for island food security.

Farm \#2 is closer to the typical farm in New Providence. This farm is 13 years old with the nine acres of land in the Cowpen Road area on lease from the government by a former entrepreneur in the heavy tool equipment industry. The clientele is primarily comprised of Bahamian residents, not Euro-American expatriates or vacationers who frequent Farm \#1. This farm combines food production with tours, parties, and retail shopping. The owner, a self-taught farmer, sells eggs, a wide variety of standard Bahamian produce, and an assortment of jams and sauces to local residents and a few restaurants. The farm doubles as an event space which is rented for retreats or camp experiences. Large pizza ovens are utilized for the quick production of casual lunches, and pitchers of freshly made juices are served to guests as part of the meal experience. Most of the tours are given to school groups to learn about farming and to discover the farming history of the island. This agritourism farm is an eclectic space. There are vestiges of the owner's earlier tool business everywhere, including heavy equipment parked at the entrance, and walls covered with metal hardware. Most of the infrastructure was built by the farmer himself, resulting in an unplanned aesthetic that stems from the cost-saving habit of building piece by piece over time without the injection of large sums of capital up front.

Farm \#2 is more representative of the type of direct agritourism that Bahamians without access to significant capital may be able to achieve. This farm is a site for domestic recreation, and, as such, its products are much more likely to be purchased by a small middle-class market for fresh produce outside of the imported grocery system. Although the farm advertises online, has a restaurant, petting zoo, and other amenities, few international tourists venture to Cowpen Road to visit. Farm \#2 is also far more concerned with educating a new generation of Bahamian youth in the ways of farming, hoping to inspire interest in agriculture as a viable career path. However, even this more egalitarian agritourism model is not likely to stem the flow of imported agricultural products. Instead of stabilizing domestic food production, direct agritourism stabilizes the existence of this one farm, as it is unlikely that the farm could afford to exist without the capacity to rent out its space for social events. But with the additional income gleaned from turning the farm into a recreational site, the farmer retains use of the land, makes a decent living with the part-time help of family, and offers produce at reasonable rates as a supplement to the goods available in the island's grocery chains.

Farm \#3 is unique in New Providence in that the farmers have an extensive, technical background in horticultural and plant science, but it is an incipient agritourism destination. 
The couple that started the farm travel constantly to conferences and workshops to maintain continuing education in the field of organic farming. The farm is an example of organic micro-farming in which large amounts of crops are creatively grown on small amounts of space, although without the aid of greenhouses or aquaponics. Located on two acres of land that is rented from a larger commercial farm in the west of the island, this farm grows some varieties of plants that are atypical for The Bahamas, such as experimental bitter Chinese greens, multicoloured radishes, Japanese eggplants, heirloom tomatoes, and kale, which are consistent with the expanding tastes of the Bahamian high-end market. In terms of agritourism, the farm is home to a weekly farmers' market that attracts local consumers, produce is sold to local high-end restaurants and individual buyers, and the farmers are active proponents of buying local, welcoming everyone to their farm and market as a form of experiential education. And yet this farm struggles with profitability, and the owners are currently unable to afford land for a more permanent farmstead. Along the lines of increasing profitability, they hope to create more value-added products and eventually expand the possibilities for direct agritourism at their farm beyond occasional tourists off the beaten path. The owners are clear that education will drive visitors to their farm, stating that they can make money from 'selling the experience' and that guests will come to learn about organic and micro-farm practices and experience local, sustainable produce.

Farm \#3 is similar to Farm \#2 in that its goods are mostly purchased by a small middleclass market as a supplement to imported items. While this farm produces more high-end and exotic crops, the current scale and seasonality of the operation is not sufficient to make significant impacts on food security. Direct agritourism is viewed by the owners as a way of increasing revenue to improve profitability of the farm and to expose both tourists and residents to an organic farm experience. However, while this farm already operates a farmers' market, it is mostly frequented by island residents. While the owners plan to expand their direct agritourism product though production of value-added goods, it is unclear that this will result in significant financial gains. With limited capital to invest, the options for expanding direct agritourism are constrained and, as seen by Farm \#2, even adding more amenities does not guarantee that tourists will come.

\section{Discussion and conclusion}

So what promise, if any, might small island agritourism hold for The Bahamas and its dreams of food security? While the existing agritourism farms currently have insignificant impacts on food security due to the type, volume, and seasonality of crops, it is arguable that they are strengthening domestic food production on New Providence. The three farms engaging in direct agritourism were the most active producers in terms of year-round consistency of the many farms that we visited because they had to have a constant supply of produce and goods for guests at their on-site restaurants and markets in addition to their wholesale clients. While the majority of the other farms produced very limited volumes of crops or livestock and left most of their land either vacant or utilized for housing, agritourism farms actively cultivated and expanded local markets for their goods. By engaging with customers, either indirectly through supplying goods for hotels and restaurants, or directly through creating a welcoming space for visitors, these farms all had some measure of success and profit. Similar to case studies from our global review, agritourism in New Providence has been used as a strategy to increase farm revenue rather than food production. However, the limited contributions of individual agritourism farms to food security could perhaps be bolstered by encouraging other farms to follow in their footsteps. 
While these farms will likely never produce enough food to render the country's dependence on imports obsolete, when taken as a collective, small agritourism farms can make significant contributions towards increasing the nutritional value and quality of domestic agriculture. If more farmers are able to engage in domestic agritourism this could ideally contribute to decreasing food insecurity by increasing the availability of high-quality, locally grown, organic and/or nutritionally rich fresh produce on the island, making such produce more desirable for more islanders. Locally accessible farms like \#2 and \#3 may be capable of changing the tastes of the Bahamian middle-class vegetable palate, injecting a desire for fresh, bitter greens and pickles into a diet steeped in Wesson Oil. In addition, agritourism has the ability to empower small farmers to retain control of their lands, resources, and futures as farms gain value in being both a site of production and a tourism destination (Sonnino, 2004). These benefits are also valuable to those who lease land, like many of the New Providence farmers.

However, these three farms also show that not all farms will be equally able to participate and reap the benefits from direct agritourism, particularly with wealthy international tourists. Farm \#1 has by far been most successful by appealing to upscale residents and foreign visitors. This success can be attributed to a number of factors including location, high-end 'green' aesthetics, and amenities - all of which are related to the farmer's investment of personal financial capital. In contrast, the unplanned and rustic aesthetic of Farm \#2, along with its location in the Cowpen Road area, have failed to attract foreign tourists. Similarly, the 'off the beaten path' charm of Farm \#3's farmers' market has been mostly patronized by island residents. New Providence is one of the most expensive destinations in the Caribbean and is marketed as an upscale beach and casino destination. As has been identified in other studies (e.g., Collins, 2000; Rhiney et al., 2015), tourists that come to the island for this type of vacation may not be interested in a more rural agritourism experience. Indeed, agritourism has largely been associated with rural tourism (Busby \& Rendle, 2000; Sikiram, 2014) and not with the 'exotic island' beach tourism of New Providence. Without significant capital, it would be difficult to transform existing farmsteads in the Cowpen Road area into upscale agritourism destinations that may be more appealing to a sufficient number of foreign tourists that frequent the island.

Further, if direct agritourism in Caribbean islands is viewed as having a certain elite aesthetic, then farms may become even more polarized. Only farmers with capital to secure prime locations and develop direct agritourism that is more reflective of high-end consumer luxury expectations will benefit, while the vast majority of farmers will continue to languish. As noted by Timms (2006), without specific measures including regulations and participatory planning, agritourism may only benefit a small minority of farmers. Agritourism is therefore not an automatically sustainable strategy. Further, agriculture is more often linked to tourism in the literature in order to promote the growth of interesting niche markets for tourism diversification, not for the development of domestic agriculture or food security (Torres \& Momsen, 2011; Turkalj et al., 2013). As many destinations increasingly desire a high-end tourist (Lundy, 2014; Ministry of Tourism, 2003) and therefore seek to promote the kind of experience a wealthier traveler would enjoy or expect, we could expect destinations to cut out poor farmers and focus on those who are able to provide 'high-quality' products that tourists are said to desire.

In a survey of foreign tourist preferences for direct agritourism in The Bahamas, Hepburn (2013) finds that farmers' markets, product tasting, and farm tours were most commonly identified as activities that visitors would be potentially interested in. While this does provide a basis for increasing direct agritourism on the island, there is a pressing need to 
explore more radical possibilities that may have a greater impact on food security and other social concerns. The practice of "critically reflexive leisure" is tourism that is self-consciously aware of the social context of leisure and the relations among leisure, power, and subsistence (Amsden \& McEntee, 2011). Viewing agritourism as a mechanism to address food justice, health, and the sustainability of communities and livelihoods, while also increasing connections to place, means that agritourism must be developed in a way that considers more than potential appeal to wealthy tourists. Encouraging the development of multiple agritourism farms like Farm \#1 that would only benefit the affluent does not improve food security or address the social and economic inequalities of the island. Agritourism created without a sense of politics or without devolution of power and economic control to the local level is potentially an accumulation strategy by which forms of subsistence wealth is actually extracted from the poor. Historically based socioeconomic inequities matter when it comes to success with agritourism, and agritourism can easily participate in exacerbating uneven hierarchies by sustaining wealthier farms (Sonnino, 2004).

Development of direct agritourism in pursuit of food security in an island as heavily dependent on tourism as New Providence must also take into account both local and visitor consumption patterns. Residents and tourists expect to have access to a wide variety of food regardless of the season, leading to an almost complete dependence on importing food. These demands for diverse food of a particular aesthetic quality limit what local markets can provide to the detriment of the agriculturalists, food culture, and food security. This is a form of food imperialism or food colonization and domestic agriculture will be unable to meet these expectations, due to seasonality and the inability to produce certain crops or livestock that do not grow well in the region. If food security is to be improved for the island, there would need to be significant changes to consumer demand and taste, a daunting task as this would require modifications to the expectations of both tourists and locals. Local farms would also have to take up the charge of producing crops that can lead to greater food security, rather than focusing primarily on herbs, microgreens, or other specialty crops. There must also be purposeful efforts to produce food to meet both tourist and local resident demands.

In the face of annual food imports dwarfing local agricultural production, island food security has become a recurring dream that has so far failed to manifest in waking life. Despite failures and setbacks, attempts to stabilize food security through the redesign of Bahamian agricultural production continue. The market for direct agritourism is just now emerging as an alternative that may hold promise to reverse the trend of agricultural decline in tourismdependent nations like The Bahamas. However, the potential for agritourism to transform food security for small Caribbean islands is constrained by demand and the consumption standards of both residents and tourists. The outlook for change does not look positive unless these larger cultural issues are faced head on in the wider society. Direct agritourism that positively impacts food security cannot follow existing models that privilege the select few and result in greater inequalities. The type of agritourism that has thus far proven to be most appealing to tourists in New Providence may just be a boutique industry for the high-end foreign visitor, not achievable for the majority of farmers, and have inconsequential contributions to island food security. Rather than promoting these unsustainable establishments, direct agritourism should be inclusive of different types of farms and farmers, take into account national food supply requirements, and actively address the need to shift consumer demands to locally viable, nutritionally rich sources of food. Unfortunately, in its current form, direct agritourism is not yet a viable solution for the food security issues of New Providence, let alone other Caribbean islands. 


\section{References}

Amsden, B., \& McEntee, J. (2011). Agrileisure: re-imagining the relationship between agriculture, leisure, and social change. Leisure/Loisir, 35(1), 37-48. https://doi.org/10.1080/14927713.2011.549194

Anderson, S.A. (Ed.) (1990). Core indicators of nutritional state for difficult-to-sample populations. Journal of Nutrition 120(11S), 1557-1600. https://doi.org/10.1093/jn/120.suppl 11.1555

Ashley, C., Goodwin, H., McNab, D., Scott, M., \& Chaves, L. (2006). Making tourism count for the local economy in the Caribbean: Guidelines for good practice. Pro-Poor Tourism Partnership.

Bagi, F.S., \& Reeder, R.J. (2012). Factors affecting farmer participation in agritourism. Agricultural and Resource Economics Review, 41(2), 189-199. https://doi.org/10.1017/S1068280500003348

Belisle, F.J. (1983). Tourism and food production in the Caribbean. Annals of Tourism Research, 10(4), 497-513. https://doi.org/10.1016/0160-7383(83)90005-1

Busby, G., \& Rendle, S. (2000). The transition from tourism on farms to farm tourism. Tourism Management, 21(6), 635-642. https://doi.org/10.1016/S0261-5177(00)00011-X

Cai, J., Leung, P., \& Mak, J. (2006). Tourism's forward and backward linkages. Journal of Travel Research, 45(1), 36-52. https://doi.org/10.1177/0047287506288869

CARICOM (2011). CARICOM View-Food Security in CARICOM. ISSN\#: 10246398. Guyana: CARICOM.

Clear, A. (2007). History of tourism in the Bahamas: a global perspective. Bloomington, IN: Xlibris.

Collins, P. (2000). Developing agro-tourism in the Caribbean. Wren Media. http://www.new-ag.info/00-4/develop/dev04.html

Cox, L.J., Fox, M., \& Bowen, R.L. (1995). Does tourism destroy agriculture? Annals of Tourism Research, 22(1), 210-213. https://doi.org/10.1016/0160-7383(95)90069-1

Department of Statistics (2015). Population projections 2010-2040. Nassau, Bahamas: Department of Statistics.

ECLAC (2008). The escalation in world food prices and its implications for the Caribbean: LC/CAR/L.179. Port of Spain, Trinidad and Tobago: United Nations Economic Commission for Latin America and the Caribbean.

Eneas, W.J.G. (1998). Agriculture in the Bahamas: its historical development 1492-1992. Swanley, UK: Media Publishing.

FAO (2015). State of food insecurity in the CARICOM Caribbean. Chile: Food and Agriculture Organization of the United Nations.

FAO (2014). Food security and nutrition in Small Island Developing States. Chile: Food and Agriculture Organization of the United Nations.

Flanigan, S., Blackstock, K., \& Hunter, C. (2014). Agritourism from the perspective of providers and visitors: A typology-based study. Tourism Management, 40, 394-405. https://doi.org/10.1016/j.tourman.2013.07.004

Fleischer, A., \& Tchetchik, A. (2005). Does rural tourism benefit from agriculture? Tourism Management, 26(4), 493-501. https://doi.org/10.1016/j.tourman.2003.10.003

Friedmann, H., \& McMichael, P. (1989). Agriculture and the state system: the rise and decline of national agricultures, 1870 to the present. Sociologia Ruralis, 29(2), 93-117. https://doi.org/10.1111/j.1467-9523.1989.tb00360.x

Harvey, E. (2011). Agritourism Development in the Caribbean: some experiences and lessons. Barbados: Inter-American Institute for Cooperation on Agriculture.

Hepburn, E. (2013). Investigating the understanding, interest and options for agri-tourism to promote food security in the Bahamas. Proceedings of the 30th West Indies Agricultural Economics Conference. 
IICA (2013). Investing in agrotourism development in the Caribbean region: final report. Port of Spain, Trinidad and Tobago: Inter-American Institute for Cooperation on Agriculture.

Karampela, S., Kizos, T., \& Spilanis, I. (2016). Evaluating the impact of agritourism on local development in small islands. Island Studies Journal, 11(1), 161-176.

Kuo, N.W., \& Chiu, Y.T. (2006). The assessment of agritourism policy based on SEA combination with HIA. Land Use Policy, 23(4), 560-570. https://doi.org/10.1016/j.landusepol.2005.08.001

Lundy, T. (2014). New strategies in tourism. Nassau, the Bahamas: The Bahamas Investor.

McGehee, N.G. (2007). An agritourism systems model: a Weberian perspective. Journal of Sustainable Tourism, 15(2), 111-124. https://doi.org/10.2167/jost634.0

Ministry of Tourism (2017). Cruise visitors by first port of entry, islands of the Bahamas 19892016. Nassau, Bahamas: Ministry of Tourism.

Ministry of Tourism (2003). Becoming the regional example of outstanding tourism management. Nassau, Bahamas: Ministry of Tourism.

Modeste, N.C. (1995). The impact of growth in the tourism sector on economic development: the experience of selected Caribbean countries. Economia Internazionale, 48, 375-386.

Moore, A. (2015). Islands of difference: design, urbanism, and sustainable tourism in the Anthropocene Caribbean. The Journal of Latin American and Caribbean Anthropology, 20(3), 513-532. https://doi.org/10.1111/jlca.12170

Mullings, B. (2004). Caribbean tourism: trouble in paradise? In T. Skelton (Ed.) Introduction to the Pan-Caribbean (pp. 97-117). New York: Routledge.

Naidoo, P., \& Sharpley, R. (2016). Local perceptions of the relative contributions of enclave tourism and agritourism to community well-being: the case of Mauritius. Journal of Destination Marketing \& Management, 5(1), 16-25. https://doi.org/10.1016/j.jdmm.2015.11.002

Pattullo, P. (2005). Last resorts: the cost of tourism in the Caribbean. New York: NYU Press.

Phillip, S., Hunter, C., \& Blackstock, K. (2010). A typology for defining agritourism. Tourism Management, 31(6), 754-758. https://doi.org/10.1016/j.tourman.2009.08.001

Pillay, M., \& Rogerson, C.M. (2013). Agriculture-tourism linkages and pro-poor impacts: The accommodation sector of urban coastal KwaZulu-Natal, South Africa. Applied Geography, 36, 49-58. https://doi.org/10.1016/j.apgeog.2012.06.005

Pirani, S.I., \& Arafat, H.A. (2016). Interplay of food security, agriculture and tourism within GCC countries. Global Food Security, 9, 1-9. https://doi.org/10.1016/j.gfs.2016.05.002

Rhiney, K.C., Walker, T., \& Tomlinson, J. (2015). Strengthening agritourism potential in the Caribbean. Netherlands: Inter-American Institute for Cooperation on Agriculture.

Rhiney, K. (2011). Agri-tourism linkages in Jamaica: Case study of the Negril all-inclusive hotel sub-sector. In R. Torres \& J. Momsen (Eds.) Tourism and agriculture: new geographies of consumption, production and rural restructuring (pp. 117-138). London \& New York: Routledge.

Rogerson, C.M. (2012). Strengthening agriculture-tourism linkages in the developing World: opportunities, barriers and current initiatives. African Journal of Agricultural Research, 7(4), 616-623.

Sharpley, R., \& Vass, A. (2006). Tourism, farming and diversification: an attitudinal study. Tourism Management, 27(5), 1040-1052. https://doi.org/10.1016/j.tourman.2005.10.025

Sikiram, N. (2014). Promoting food safety and security in rural tourism destination. SHS Web of Conferences 12. https://doi.org/10.1051/shsconf/20141201062

Sonnino, R. (2004). For a 'piece of bread'? Interpreting sustainable development through agritourism in Southern Tuscany. Sociologia Ruralis, 44(3), 285-300. https://doi.org/10.1111/j.1467-9523.2004.00276.x

Su, M., Wall, G., \& Wang, S. (2017). Yujiale fishing tourism and island development in Changshan Archipelago, Changdao, China. Island Studies Journal, 12(2), 127-142. 
https://doi.org/10.24043/isj.38

Telfer, D.J., \& Wall, G. (2000). Strengthening backward economic linkages: local food purchasing by three Indonesian hotels. Tourism Geographies, 2(4), 421-447. https://doi.org/10.1080/146166800750035521

Telfer, D.J., \& Wall, G. (1996). Linkages between tourism and food production. Annals of Tourism Research, 23(3), 635-653. https://doi.org/10.1016/0160-7383(95)00087-9

Tew, C., \& Barbieri, C. (2012). The perceived benefits of agritourism: The provider's perspective. Tourism Management, 33(1), 215-224. https://doi.org/10.1016/j.tourman.2011.02.005

Thacker, N., \& Perrelli, R. (2012). Caribbean growth in an international perspective: the role of tourism and size. IMF Working Paper 12/235. Western Hemisphere Department: International Monetary Fund.

Thomas, A. (2012). An integrated view: multiple stressors and small tourism enterprises in the Bahamas. New Brunswick, NJ: Rutgers The State University of New Jersey.

Timms, B. (2006). Caribbean agriculture-tourism linkages in a neoliberal world: problems and prospects for St Lucia. International Development Planning Review, 28(1), 35-56. https://doi.org/10.3828/idpr.28.1.2

Torres, R.M., \& Momsen, J.H. (Eds.) (2011). Tourism and agriculture: new geographies of consumption, production and rural restructuring. London \& New York: Taylor \& Francis.

Torres, R., \& Momsen, J.H. (2004). Challenges and potential for linking tourism and agriculture to achieve pro-poor tourism objectives. Progress in Development Studies, 4(4), 294-318. https://doi.org/10.1191/1464993404ps092oa

Turkalj, Ž., Ham, M., \& Fosić, I. (2013). The synergy of sustainable tourism and agriculture as a factor of regional development management in Croatia. Ekonomski Vjesnik, 26(1), $71-82$.

Wiley, J. (1998). Dominica's economic diversification: microstates in a neoliberal era? In T. Klak (Ed.) Globalization and neoliberalism: the Caribbean context (pp. 155-77). Boston Way, MD: Rowman \& Littlefield. 